Please do not remove this page

RMIT

UNIVERSITY

\title{
Understanding the negotiation of paid and unpaid care work in community services in cross-national perspective: the contribution of a rapid ethnographic approach
}

Charlesworth, Sara; Baines, Donna

https://researchrepository.rmit.edu.au/esploro/outputs/9921861778801341/filesAndLinks?institution=61RMIT_INST\&index=null

Charlesworth, S., \& Baines, D. (2015). Understanding the negotiation of paid and unpaid care work in community services in cross-national perspective: the contribution of a rapid ethnographic approach. Journal of Family Studies, 21(1), 7-21. https://doi.org/10.1080/13229400.2015.1010263 Document Version: Accepted Manuscript

Published Version: https://doi.org/10.1080/13229400.2015.1010263

Repository homepage: https://researchrepository.rmit.edu.au

CC BY-NC-ND V4.0

(C) 2015 Taylor \& Francis

Downloaded On 2023/04/26 12:45:37 +1000 


\title{
Pre-print of:
}

Charlesworth, S., \& Baines, D. (2015). Understanding the negotiation of paid and unpaid care work in community services in cross-national perspective: the contribution of a rapid ethnographic approach. Journal of Family Studies, 21(1), 7-21. https://doi.org/10.1080/13229400.2015.1010263

\begin{abstract}
In the community services sector government policies and practices around the tendering and contracting out of services have a direct impact not only on the wages and conditions of care workers, but also on these workers' capacity to combine paid care work and unpaid care. The paper reflects on the qualitative methods employed in a large cross-national comparative study of community sector agencies, which contributes to a rich and gendered understanding of how work and family is 'done' in such workplaces. In particular, the paper focuses on the iterative 'rapid' ethnographic approach employed in the study and its macro and meso theoretical underpinnings, which are valuable in making the link between workplaces and the institutional and policy contexts in which they are located. The paper briefly illustrates the utility of this layered qualitative approach through selected findings on ways in which paid care work can trump unpaid care responsibilities.
\end{abstract}

\section{INTRODUCTION}

In this paper we focus on the negotiation of paid and unpaid care work in the community services sector, ${ }^{1}$ drawing on a large cross-national comparative study of non-profit (NP) agencies to address two questions. Firstly, we ask how the distinctive qualitative case study approach used in the study might assist the exploration of changing work relations in the NP community services sector in four countries with similar but still distinctive highly restructured and retreating liberal welfare states. Secondly, we ask what such an approach, with its integration of workplace and of more macro social policy perspectives, might offer qualitative work-family research more generally in better understanding how employees negotiate work and family. We argue that the qualitative methods employed in the study and the multi-level approach that informs them illuminate the broader social and regulatory context within which diverse groups of care workers negotiate the changing dynamics of their unpaid care responsibilities at home and their paid care responsibilities at work.

\section{Background and perspectives}

Since the 1980s there has been an incremental but inexorable move to a market or neoliberal state in many developed economies that has sought to transfer social responsibilities from the state to civil society (Bach \& Bordongna, 2011). As part of the shift from a redistributive state to a residualist/minimalist state, the delivery of community services to vulnerable populations has been characterised by cuts and tighter targeting of services, by managerialist administrative reforms designed to reduce government outlays and direct service provision, by cost-shifting between tiers of government, and from government to communities and families (Hancock, 1999; Evans \& Shields, 2002; Cunningham, 2008). The outsourcing of community services in countries such as Australia, Canada and the United Kingdom has been accompanied by demands for efficiency, 
accountability and lean production particularly in the non-profit (NP) sector (Baines, 2004; Evans, Richmond \& Shields, 2005; Cunningham \& James, 2011). Neoliberal governance, or what is known as New Public Management (NPM), has provided a rationale for the cutting and controlling of costs by increasing accountability metrics and introducing agency-wide competitive performance management. Both these processes impact directly on front line care workers shaping their pay and working conditions (Baines, 2010; Rasmussen, 2004; Cunningham, 2008), and are underpinned by gendered expectations of self-sacrifice by workers (McDonald \& Charlesworth, 2011).

In most developed economies the community services workforce is highly feminised and while formal care is increasingly marketised, its links with the unpaid care work women do for 'free' lingers in the funding of and organisation of work in NP community services agencies (Charlesworth \& Marshall, 2011). The skills required in care work are often understood as 'personal' skills, attributes of the women who mainly provide these services with women's assumed natural abilities for emotional work expected to be available to employers when they are hired (Rasmussen, 2004). Indeed, the highly gendered nature of care work provides a sector-wide institutional logic (McDonald \& Charlesworth, 2011) that shapes the expectations that employers, clients and workers themselves have of the predominantly female workforce's capacity to provide elastic and endless care regardless of wages and working conditions (Charlesworth, 2010).

Against this backdrop, a large comparative study of NP community services agencies was developed, entitled 'Convergence and particularity: International comparisons of the non-profit social services sector'. The framing of the project was informed by insights from feminist political economy (Aronson \& Neysmith, 2006; Vosko, 2010), drawing on an understanding of how economic and political institutions shape and interact with gender regimes and work/care regimes and the 'doing' of gender in organisations (Pocock, 2005; Vosko, 2002; Folbre, 2001). The project was also informed by labour process theory (Baines, 2004; Cunningham, 2008; Hampson \& Junor 2010), which can help illuminate the dynamics of work relations and the connections between workplace and the wider social system (Thompson \& Smith, 2009, p. 916), including in community services work (Cunningham, 2008; McDonald, 2006). The main aims of the study were to: (1) investigate the local impacts of globalised models of restructuring across Australia, Canada, New Zealand and the United Kingdom in the community services sector, focusing on the processes of gendering; (2) explore the local and national level structural and policy changes behind the convergence and particularities in NP community services provision and working conditions, and (3) investigate the links between emerging aspects of community services work under restructuring and growing challenges within the sector across the four countries.

In this paper we focus on distinctive qualitative methodology used in this study of NP community services and its potential for use in organisationally-located work-family research. While this project was not explicitly conceived of as a 'work-family' study, the methodology used provides a platform for the integration of both policy and workplace perspectives in undertaking work-family research. The work-family literature has grown exponentially over the last 20 years focused both on the growing pressures on workers, families and workplaces with the increased labour force participation of women and on state level or workplace policies designed to 'deal' with these pressures (for a review see Bianchi \& Milkie, 2010). Until recently however, much work-family 
research has tended to bifurcate into studies focused on government action on social and labour market policies as a crucial determinant of work-family balance or integration (e.g. Gornick \& Myers 2003) or studies concerned with organisational policies or cultures that support or frustrate work-family reconciliation (e.g. Kossek \& Lambert, 2005). Our experience in conducting the comparative study of NP community services agencies suggests the benefits of a more contextualised approach where the impact the broader policy and sectoral contexts within which an organisation operates have on the lived experiences of employees can also be explored.

Such an approach is of specific value in better understanding the 'work-family' problem in the NP community services. This problem can be viewed from two different perspectives. Firstly, from a social policy perspective that focuses on the retrenchment of the welfare state and the contracting out of previously government-provided services to the for-profit and NP sectors. Accompanying this shifting role of the state is the growth in and demand for paid care work with increased female employment participation. Thus, paradoxically, there are pressures for both more wide-spread and a greater range of services in a contracting state. While not commonly framed as part of the workfamily infrastructure, the non-government sector provision of community services provides part of the paid care architecture that enables women to engage in paid work (Applebaum, Bailey, Berg \& Kalleberg, 2002). At the same time, while the NP community services is a growing employer of women in most countries, as a sector characterised by low wages and poor conditions, it arguably provides an inadequate scaffolding for good work-life balance.

The 'work-family' problem in the NP community services can also be understood from a regulatory or labour studies perspective which takes as its starting point the low wages and poor conditions in the sector (Kalleberg, 2009; Vosko, 2006; Charlesworth, 2010). These poor conditions are seen as a barrier to the expansion of social care at the very time there is increased demand for paid care work, both due to the increased workforce participation of women and the aging of the population (Charlesworth, 2012). They are also seen as a barrier to decent work; that is, to the decent pay and working conditions that underpin decent care, both for those who provide paid care and those who rely on it (Applebaum et al, 2002). Finally, the inadequate pay and conditions can be seen as a barrier to gender equality, not only in paid work but also in the undervaluing of unpaid care which in turn informs the gendered undervaluing of the paid care work workers in the sector provide (Meagher, 2006).

In the next section we outline the distinctive features of the qualitative case study approach on which the cross-national study of NP community services draws before detailing how the rapid ethnographic approach was operationalised in the agency case studies undertaken as part of this study. In the following section we then draw on some emergent themes in our analysis of case study data, including a widespread acceptance that paid care work trumps unpaid care work, low pay as a barrier to work-family balance, and high workloads undercutting practical access to family-friendly policies where they exist. In conclusion, we argue for the utility of our approach in undertaking more nuanced and contextualised work-family case studies. 


\section{CASE STUDY APPROACH}

\section{Qualitative approach}

The qualitative approach we have used in the comparative study draws on rapid ethnography (Millen, 2000; Szebehely, 2007). Rapid ethnography (RE), also known as 'short-term' ethnography (Pink \& Morgan, 2013), 'rapid assessment' (Beebe, 2001) and 'quick ethnography' (Handwerker, 2001), is a form of multi-method ethnography involving data collection from numerous sources over a relatively short period of time; typically weeks rather than months (Harris, Jerome, \& Fawcett, 1997). RE typically includes interviews, participant observations, document reviews and sometimes surveys and focus groups (LeCompte \& Schensul, 1999). RE can be distinguished from what has been called 'quick and dirty' ethnography, which accepts that only limited and incomplete understandings can be gathered, with the RE approach, which is more intense, deliberate and theoretically engaged, representing a practical and analytical entry point into the lives of others (Pink \& Morgan, 2013, p. 353). RE is seen as a particularly effective method for investigating pressing social issues that benefit from a relatively rapid production of findings as well as longerlasting contributions to larger debates and bodies of knowledge (Handwerker, 2001; Millen, 2000).

Three key elements of the RE approach described by Millen (2000) include: the use of a targeted research question and focus - 'a telephoto lens' rather than the 'wide angle lens' of traditional ethnography; the use of multiple interactive observations both by different researchers and from the different standpoints of managers and workers; and the use of collaborative and iterative data collection and analysis. The use of multiple researchers has a number of advantages in negotiating policy and cultural issues in cross-national studies and in deepening understandings of a specific context through multiple analyses of the same events (Millen 2000). In particular, involving at least two or more researchers in all aspects of data collection - where typically one is more of an 'insider' in terms of knowing the case study site and one may be less familiar - an 'outsider' - and also in data analysis ensures shared opportunities for reflection and critique (see also Rubin \& Rubin, 2005).

RE typically involves extensive research and pre-planning is undertaken before the actual onsite data collection (Millen 2000). This includes, for example, pre-interviews within and outside the case study site to deepen understanding of the location of the case study site relative to other similar organisations in the field. Informal discussions with informants outside the organisations are also useful in gaining a clearer perspective on how the case study site is situated within its industry context, both in terms of similarities and differences. RE also involves multiple site visits, which facilitate naturalistic observations and interactions as well as an iterative process whereby issues that come up in observations or interviews can be explored both formally and informally with informants in their own location or setting.

The goal of RE is to produce a multi-layered textured analysis of a slice of life in an organisation and in our study - of the everyday life of paid care workers in the NP community services both from the perspectives of the workers and their managers. RE is particularly suitable to addressing the sort of problems our study is concerned with because it supports the collection of sufficiently complex descriptions of social life that facilitate both the exploration of surface and deeper themes 
in the organisation of work and making links with the local and global institutional and policy contexts of the agencies we are studying (Baines \& Cunningham, 2013, p. 74). RE not only has the concrete benefit of reducing the burden on the case study organisation and making effective use of the increasingly limited research funds in the social sciences, it also facilitates making practical and theoretical links between the 'everyday' life of community services work to the changing organisational conditions and context in which it is performed (see Szebehely, 2007).

\section{The comparative study of NP community services}

The comparative study of NP community service agencies built directly on the earlier work of one of the three key researchers involved in the project. Through both case studies and policy analysis this research had identified, among other things, the extensive unpaid work undertaken by frontline NP community services workers to make up for short-falls in government funding in the Canadian context (Baines, 2004, 2010). Through engagement with an Australian researcher and a Scottish researcher investigating similar issues in their own countries, the current study project was conceived and refined through several small local pilot studies. It ultimately secured funding from the Canadian Social Sciences and Humanities' Research Council.

The three main researchers are all multidisciplinary researchers with different but complementary discipline backgrounds, including social work, labour studies, legal studies, management and employment relations and gender studies. Over the periods of sabbatical the lead Canadian researcher spent in Scotland, Australia and New Zealand and in the process of developing the study, the cross-national collaboration between the three researchers deepened, providing the basis for the high degree of trust, overlapping interests and common purpose that underpinned the critical reflexive research practice that developed (Creswell \& Miller, 2010, p.127). In undertaking the data collection at case study sites, local PhD students and researchers were also bought in to the project. This was particularly important in New Zealand, which, while part of what is known as 'Australasia', has its own distinctive community services sector and funding regime. As explored further below our individual expertise in the policy and institutional context of community services work in our own countries became an important methodological tool employed in the project.

Ethics approval to conduct the research was obtained at each of the relevant universities, and, in several cases, through additional in-house ethics processes at individual agencies. Within each country, the local researcher had the responsibility of identifying possible case study sites. This was achieved through both local knowledge and scoping interviews with other community service practitioners, peak sector organisations and relevant union officials. Our focus was on large multiservice agencies that were well-regarded and seen as effective agencies in their local context. Once an agency had agreed to participate, the local researcher undertook an initial scan of relevant agency documents and in discussion with senior management, negotiated both access to potential interviewees and set up at least three formal observations at each case study site. To gain a range of perspectives both frontline care workers and managers in different parts of the agencies were targeted for interview. Where workers and managers agreed to participate, interviews were scheduled over a one week or two week intensive period. Following the initial interviews and participant observations, subsequent interviewees were approached for their potential contribution to our study. 
We used the same semi-structured interview profoma in all the case studies. The topics we covered, moving at the interviewee's pace, included: the worker's background, the nature of their work (and where the interviewees were managers, the kinds of workers they supervise), the pace of work, their workloads, changes in client populations, work environment, systems of allocating work, wages and conditions, the expectations of managers/clients, what makes work easier/more difficult, unpaid work, managing paid and unpaid care work, how they are supported or not by managers, abuse and violence at work and finally, plans and hopes for the future.

Thirteen case studies were completed between 2011 and 2013; four in Canada and three in each of Australia, Scotland and New Zealand. Each was focused on large agencies in urban areas or large regional cities with the numbers of employees varying between just under 100 to over 800 . Each agency provided a range of services to vulnerable populations, with multiple and diverse funding contracts from different tiers of government. While these services varied from country to country and from case study site to case study site, they included services such as housing/homelessness support, addictions services, food budgeting and income referral, child/family services, disability services and elder support. In each agency formal interviews were undertaken with between 12 to 25 individual managers and employees with supplementary formal interviews with relevant union officials and policy practitioners in the same location. In addition, between three to five formal observations at different sites within each case study agency were also undertaken.

We have now published several articles that both focus on specific country findings as well as international comparative findings on a range of diverse topics, including work organisation, workplace violence and gendered managerialism (e.g. Charlesworth \& Baines 2011; Baines \& Cunningham 2011; Cunningham, Baines \& Charlesworth, 2014; Baines, Charlesworth \& Cunningham, 2014). While in such articles we only briefly describe the methodology employed in order to focus on the specific findings, we reflect below on how we operationalised the RE methodology we employed, which has proved an effective way of both undertaking the case studies and analysing the data we gathered.

\section{Operationalising RE}

A distinguishing feature of our methodology that extended the typical RE approach was that it made active use of the different standpoints of the three researchers. While each had significant knowledge about the policy and funding context of NP community services in their own countries, each also drew on different disciplinary backgrounds and paradigms. So rather than using a 'country' approach, where each researcher prepared a national report based on their own country, or a 'safari' approach, where just one researcher collected data in several countries (see Szebehely, 2007, p.6), the comparative study of NP community services was designed to make conscious use of an insider/outside perspective at each case study site through the pairing of a local and foreign researcher (Baines \& Cunningham, 2013).

This approach proved helpful in the preparation before we went on on-site because it provided the impetus for the local researcher to put both local literature and policy documents in context for the outsider researcher. It also provided a platform for the outsider researcher to question local takenfor-granted assumptions about the organisation and doing of care work in a particular national context. For example, the very different forms of unionisation in Canada and the other three countries was initially a challenge as the researchers sought to understand the different role unions 
and union membership played in setting and enforcing the conditions of community services workers, both within particular sites and more generally within the local context. Likewise, while the outsourcing and funding regimes in community services are similar in Canada, Scotland and Australia, one of our case study sites in New Zealand relied mainly on philanthropic and private fundraising for its operation rather than tied government grants. While it is widely accepted that inadequate funding constrains the wages paid to community services workers, we were surprised to find that this particular agency paid well below the local norm for community services workers. This finding suggests the dominance of an 'institutional logic' in the sector (see McDonald \& Charlesworth, 2011) that works to normalise low pay even where there are few actual constraints on agency funding.

Once the relevant background for a particular agency was established and informal scoping interviews with others in the local sector were undertaken, we typically spent a week in a particular agency with two or more researchers working full-time over that time to gather the bulk of the data we required. While we had set up joint interviews with key informants before that time, if we needed to accommodate the availability of informants we also undertook separate interviews and debriefed shortly afterwards. The researchers debriefed at the end of each day and at the beginning of the next and decided how we might follow up certain issues that emerged, discussing what came up at participant observations and in interviews. This allowed us to follow up particular issues as they arose while we were onsite and helped us reach data saturation pretty quickly (Bowen, 2008). It also enabled us to iterate preliminary findings into subsequent interviews and observations, clarifying initial impressions and deepening data collection.

The naturalistic participant observations we undertook included both more formal observations negotiated with the agency before we started, for example of a day care program for people with acquired brain injury, and also the more informal 'hanging around', talking to staff in reception areas or in lunch rooms. We have found that in some cases we get to see if the way we have been told the organisation works actually does so in practice. The RE approach thus facilitates the exploration of the intersection of policy and practice. For example, while waiting in the reception at one of the New Zealand agencies, we noted that some of the staff members on the contact board shared the same surname. On remarking on this to the receptionist we were told that three of the senior managers were all related, which provided a small but important insight into the paternalistic ethos we had found at this agency, more typical of small business or family-run enterprises, rather than the more formal managerialism that senior managers at this agency had asserted was their practice.

After the intensive 'blitz' on-site data collection, at many case study sites we needed to arrange follow-up interviews and re-review documents we had collected. As part of our commitment to knowledge mobilisation, we provided formal written feedback to all the agencies involved on the main issues that came up during our fieldwork at that particular agency as well as a comparative analysis of how each agency sat in relation to others in the study and in the sector more broadly. Most of the agencies were very interested in the comparative perspective as it provided an opportunity to see how agencies in other parts of the world grapple with the same issues. Our reports and presentation of findings to the agencies studied also presented an opportunity for management and employees to question and clarify some of our broad findings. 
A consistent theme that emerged across the case studies generally was that while the inadequacy of government funding structures pay and conditions in terms of minimum standards in the sector or in a program and the actual work practices on the ground, the gendered expectations and acceptance of self-sacrifice not only of management but of workers themselves also play a central role (Charlesworth \& Baines, 2011; Cunningham et al., 2014). However the ways in which this played out not only varied from country to country but also from agency to agency.

Managing paid and unpaid care work was a topic we explored in most of our interviews across the 13 case study sites and it formed an important background to our other findings such as around the inadequacy of government funding that structures pay and conditions, agency mission and worker identity, lean work organisation, the ubiquity of violence and the impact of the strict demands by government funding bodies for extensive documentation. In the next section we briefly highlight some of the findings from our analysis of the ways care workers negotiate their unpaid care responsibilities at work in the context of lean work organisation and low pay. We suggest that it is our methodological approach, which both pays attention to and links the macro and the meso levels of analysis, that enabled us to surface these themes.

\section{NEGOTIATING WORK \& FAMILY: INSIGHTS FROM RE}

Despite the substantial media and policy prominence given to the problem of work-family in all four countries, it was not an issue that surfaced quickly in our agency interviews. This is perhaps surprising because the majority of those who work in the sector are women and many have significant dependent care responsibilities for children as well as for aged and disabled family members. It is even more surprising given that paid care work is often seen as an extension of women's unpaid family work (England, 2005). We found numerous instances of both men and women first of all declaring they had no family responsibilities then, for example, going on to describe caring for a sibling with mental health issues or for a partner with debilitating health issues. For example, after numerous informal interactions over the course of a few days, we interviewed one of the reception staff at a New Zealand agency, who was an Indigenous person. Initially, she told us that she had no care responsibilities at home. The insider interviewer knew that this was not typical of Indigenous communities and further probing revealed that the worker had heavy care responsibilities across extended family which she took for granted and had not thought merited reporting. Without this insider knowledge, we would have missed valuable data and the insights it provided. As a result we began to probe more deeply on the question of care responsibilities with all our interviewees.

In an example of RE's usefulness in gaining insights into emerging trends in work-life dynamics, during an observation in a group home in Scotland for people with intellectual disabilities, we were struck by the fact that none of the male workers had ever worked in care before and all had recently left or been made redundant in traditionally male jobs such as trucker, factory worker, construction worker, and so forth. With some minor prompting, these male workers spoke openly about their challenges with work-life balance and had chosen the job because of opportunities for 'juggling' care responsibilities and because someone, usually a woman, had told them they would 'be good at it' (care work). Our local researcher reminded us that unemployment for men was a long term and growing problem in Scotland since the 2008 general financial crisis, and that men seemed to be 
moving into care work in increasing numbers. This prompted us to start to ask questions about how masculinities operate in different programs within the same agency, as well as shifts in male/female employment in the restructured NP services in the context of growing austerity and how this might be changing paid and unpaid care work. This, in turn, caused us to undertake closer observations and interviews with men across the agency under study, and in subsequent case studies in order to confirm these preliminary findings and expand them into larger themes and theorizations (Baines et al, 2013, 2014). Our multi-country findings, prompted by our initial observational data in one workplace, pointed to a higher and growing presence of men in care work in the NP sectors in the two countries we studied with high male unemployment, as well as shifting relationships in the workplace and home. This continues to be a fruitful line of inquiry. In a similar vein, our data suggest that despite differences in policy at the national and local levels, a convergence across the countries we studied was observable in terms of policy impacts on employee work-family balance in the NP sector. One of clearest and most consistent of these impacts was the increasing reliance on unpaid work to maintain or extend the work of underfunded agency in the context of constrained government funding and policies that have come to be known as austerity.

In 2002 Paul Pierson argued that the governments of affluent countries had been pursuing policies of 'permanent austerity' for some time and would likely intensify this approach (2002). His words were confirmed after the 2008 financial crisis when even countries who had not experienced recession introduced policies aimed at significant reductions in welfare state provisions, restructuring of labour markets and cutbacks in most areas of governments spending (with the exception of the military). ${ }^{2}$ The additional hours of unpaid work in the agencies where formal national austerity policies had a material impact in reduced government funding available to undertake the same services, such as in Scotland and Canada, intensified the difficulty workers had in balancing work with caring for their own children and families. For example, our observation data at a Canadian case study showed that managers depended on unpaid care to extend the work of the constrained agency, 'we couldn't do without the extra hours people put into this place'. In interviews, many workers told us they felt pressured to work past their paid hours and vulnerable to discipline. One worker spoke for many in her comment, 'I feel like everyone thinks I am selfish if I leave on time and I worry that when they are looking around for the next person to lay off, it'll be me, so I stay late but my kids deserve better'. However in national contexts where government austerity policies had not been formally introduced, such as New Zealand and Australia, we found a political austerity 'ethos' had also worked to reduce government funding in some specific program areas.

One of our strongest findings on the theme of work and family, despite some significant gender differences that reflected both agency and national context (e.g. Baines, Charlesworth \& Cunningham, 2014), was that there was a widespread acceptance by both workers and line managers that paid care work trumps unpaid care work. Few managers explicitly argued that in the NP sector it was unreasonable to expect 'extra concessions', as a manager in one of the NZ agencies described family friendly policies. However while many managers who were aware of the difficulties faced by employees in juggling paid and unpaid care work were sympathetic, they saw such difficulties as part and parcel of working in the sector. A senior manager at one of the Australian case study agencies ruefully noted that the agency sometimes 'over-used the dedication' shown by employees to service delivery. 
The concept of the 'greedy institution' is useful for understanding the social processes around this acceptance. As Rasmussen (2004) argues, the realities of inadequate resources and high service user demand, characteristic of the restructured, leaned-out NP community services sector and the leaned out social welfare state, create the conditions in which agencies are 'greedy' for the time and energies of front line workers. In order to feel ethical as care workers, most front line workers respond with excessive efforts on to meet the unending demands of the workplace. Care workers' commitment and willingness to take responsibility for the aims of the organisation in a situation of constrained resources and excessive demands, places workers in a situation over which they have no control (Rasmussen, 2004, p. 523) and from which employers benefit in the form of more labour, including unpaid overtime and other forms of self-exploitation. The fact that most employees are working with disadvantaged and vulnerable populations makes it very hard for many workers to prioritise their own unpaid care responsibilities. As a worker in a Canadian case study site quipped, 'the wages are terrible here anyway so why not work even more hours for no pay if it means you can keep a program afloat or keep someone from having to put their kids to bed hungry'.

However it is not only care institutions, such as the agencies in our studies, which can make excessive demands of workers but also the families of care workers. Both the family and care services, including the agencies we studied, are greedy institutions not only requiring labour from workers but motivating this work by invoking active commitment and loyalty while simultaneously providing opportunities for real worker satisfaction when they put their care values into practice (Franzway 2003, p. 4). This makes for a real tension between work and family particularly for female care workers. For many of our interviewees across the 13 case studies there was strong sense that prioritising the demands of service users 'goes with the territory' of working in NP community services agencies. Yet because women's lives are still generally more likely than men's to be dominated by the greedy institution of the family, it is women who are most likely to have to juggle the demands of providing care in their own families and the demands of paid care work.

For many female workers, however, prioritising the demands of paid care work also serves to undercut some of the satisfaction and identity they gained from being 'good' family carers. At one of the Scottish case study sites, a social worker, whose work involved supporting families in crisis, ironically described how her long hours and heavy workload limited her capacity to meet her professional expectations of what constituted positive family functioning in her own family. In one of the New Zealand cases, our early recognisance suggested that though the agency had a positive reputation within the industry, it had recently been through a difficult restructure, including several redundancies. This attuned us to ask about restructuring and staff changes and to observe work organisation, staff morale, workplace culture, and so forth. In interviews, frontline staff told us that the restructure had been 'harsh and destabilising' for staff and service users, and 'seemed to fundamentally undermine the (agency) ethos'. Though the restructuring had ended, workers reported fears that if they did not work beyond the expectations of their jobs, including unpaid overtime, they would be the next to lose their jobs. One long time worker echoed the stress and conflicts between negotiating paid and unpaid care work expressed by many when she told us, 'I go home everyday with a pounding headache. My poor kids get the worst of me while this place takes and takes.' 
Much of the work-family literature focuses on the presence of flexible workplace provisions or on social policy that provides the social care infrastructure needed by working carers, such as childcare yet there is less emphasis on decent wages as part of this infrastructure. While there are differences in the quantum of wages paid across the NP community services sector, what is clear is that in all four countries in our study pay rates are low in comparison with other workers in those national contexts (Cunningham \& James, 2011, p.229). In all our case study sites, the relatively low pay of community services work was an issue raised not only by workers but also by managers, many of whom were concerned about the impact of low pay on attraction and retention. In both Canada and Australia the large disparities in pay between community services workers and workers employed directly by government doing similar work were frequently noted by participants. Indeed such disparities have formed the basis of equal pay claims in the relevant employment jurisdictions in those countries.

However while low wages are seen as a fact of life in the community services sector, far less attention has been paid to the low pay as a work-family problem in the sector. However, the issue of pay and its impact on workers' current and future caring responsibilities and family relationships was one that surfaced strongly in all our cases study sites. For younger workers, the low rate of pay not only shaped their present but constrained their future plans. In one of the Australian case studies, a young Aboriginal youth worker told us that as much as she loved her job it would not be an option if she had a family in the future 'If I had a family, there is no way I could afford to keep working here'. She described how she was able to make do in her current situation by living in share accommodation and buying clothes from second-hand shops. Other workers pointed to the fact that their partners or other family members directly subsidised their work in community services. Several women and one man described how they were able to 'afford' to work in their community services jobs because their partners earned enough to cover joint household expenses, 'If I was the sole breadwinner, I couldn't probably afford to work here'. In one extreme case a social worker at one of the New Zealand agencies described how she was at times dependent on her adult daughter for groceries and helping her get by because of her low wages and having to cover her fuel costs when she had to travel to different agency sites. Other interviewees spoke about how family members, such as parents and sisters, indirectly subsidised their paid work through providing the familial care for children and older relatives that the worker was not available to provide.

Despite its material consequences, the fact of low pay itself was rarely questioned, even by workers. It was accepted as a fact of life in the sector. While some line and senior managers regretted the consequences low pay had for employee turnover, others explicitly referred to the benefits workers derived from doing meaningful work which was assumed to compensate for in adequate wages. At one of the Scottish case study sites, a line manager remarked that the ethos behind the agency's mission was more rewarding to staff than just a pay packet at the end of the week. The discourse that low pay is a trade-off for what is seen to be the intrinsic value of care work is a dominant one, shared not only by workers and managers but also one that characterises the sector and the government funding regimes that place such a low price on paid care work. As England (2005) notes, focusing on the intrinsic motives that drive many care workers makes it easier both for the work in paid care work to be hidden and for low wages to be justified. 
Finally, there was an assumption by some line managers across the 13 case studies that the direct care work undertaken in the NP community services is innately 'family friendly'. In many of the agencies this was reflected in formal agency policies or collective agreements, which provided for access to flexible working-time arrangements, such as time in lieu or variable start and finish times. However for many workers the high workloads created through the lean work organisation that characterises the sector (Baines, 2010), which in turn is produced by the government contracts and outsourcing arrangements of national funding regimes (Cunningham, 2008), work to undercut practical access to formal family-friendly policies within agencies. Workers at many of the agencies with formal entitlements in place described how they found it hard to take the time in lieu or the even sick leave to which they were entitled because of the relentless demands of their work. So despite the view that paid care work is viewed as flexible and can somehow enable women, in particular, to manage their own care responsibilities, there is considerable blindness in the NP community services to paid care workers as embodied working carers.

\section{CONCLUDING COMMENTS}

In this paper we have highlighted the utility of a rapid ethnographic approach to better understanding the 'doing' of work and family in a particular industry, in this case the NP community services sector. Our use and development of the RE approach in a cross-national study allowed us to link a macro-level focus on government funding regimes in each of our four countries to a meso level focus on work organisation and practice in particular agency workplaces. In many instances it was our RE team approach to interviewing where one interviewer had insider information that permitted us to delve more deeply into topics and gather richer data that shifted our analysis and impressions. In turn our interviews at the 13 case study sites enabled us to employ a more micro-level lens to view how the interaction of different funding regimes and agency contexts shaped how particular workers and managers negotiated paid care work and unpaid care.

In short, the RE approach lends itself extremely well to a contextualised analysis of how workers in the sector negotiate paid and unpaid care work and to making practical and theoretical links between the 'everyday' life of community services work to the changing organisational conditions and context in which it is performed (Szebehely, 2007). In particular we suggest that in community services, a macro-level focus on the national and local social policy and funding context, a meso level focus on the particular agency context, and a more micro-level focus on the impacts on different groups of workers provides the basis for a deeper and richer assessment of the 'doing' of work-family.

While the cross-national study on which this paper draws was focused more broadly on an investigation of the local impacts of globalised restructuring in the community services sector, the multi-layered qualitative approach we have outlined here presents a useful alternative to more traditional work-family workplace case studies which tend to be organisationally bounded. That is, much work-family research employs an 'organisation as an island' lens where few connections are made between organisational level practices, employees' work-family concerns and the environments in which workplaces operate. Making a link between workplaces and the broader institutional and social context in which they are located can work to deepen our understanding of complex work-family phenomena. For example, the low wages, that practically constrain workers' 
negotiation of paid and unpaid care work, can be traced back to the government outsourcing of many community services to the NP sector in order to contain welfare state spending and reduce deficits (Kosny \& MacEachen, 2010). Nevertheless, the direct and indirect subsidy of paid care work through other income earned in families and the unpaid care work of other family members is not something that characterises only community services work, but also paid work and employers more generally (see Conaghan, 2004, p. 72). It is only through employing a methodology that enables more nuanced and contextualised work-family case studies that such linkages become apparent.

\section{ACKNOWLEDGMENTS}

This research received funding from the Canadian Social Sciences and Humanities Research Council International Opportunities Fund.

The authors are grateful for the feedback and suggested revisions by the editors and the two anonymous reviewers. We also wish to thank the research participants in all our case studies.

\section{NOTES}

${ }^{1}$ This sector is variously known as 'social services' in Canada and New Zealand, 'community services' in Australia and the 'voluntary social care' sector in the United Kingdom. The community services sector includes agencies providing a wide range of social assistance services, such as homelessness, unemployment and addictions services, material aid, family and child support and disability support.

${ }^{2}$ The terms austerity and austere are used here to denote this policy direction and the neoliberal ideology accompanying it rather than a specific moment in time.

\section{REFERENCES}

Appelbaum, E., Bailey, T., Berg, P., \& Kalleberg, A. L. (2002). Shared Work, Valued Care: New Norms for Organizing Market Work and Unpaid Care Work. Economic Policy Institute Washington, DC.

Aronson, J., \& Neysmith, S. M. (2006). Obscuring the costs of home care: Restructuring at work. Work, Employment \& Society, 20(1), 27-45.

Bach, S., \& Bordogna, L. (2011). Varieties of new public management or alternative models? The reform of public service employment relations in industrialized democracies. The International Journal of Human Resource Management, 22(11), 2281-2294.

Baines, D. (2004). Caring for nothing: Work organization and unwaged labour in social services. Work, Employment and Society 18(2): 267-295.Baines, D. (2010). 'If We Don't Get Back to Where We Were Before': Working in the Restructured Non-Profit Social Services. British Journal of Social Work, 40(3), 928-945.

Baines, D., Charlesworth, S., \& Cunningham, I. (2014). Changing care? Men and managerialism in the nonprofit sector' Journal of Social Work, September 7, 2014, DOI: $10.1177 / 1468017314548149$. 
Baines, D., Charlesworth, S., Cunningham, I. and Dassinger, J. (2012) Self-monitoring, selfblaming, self-sacrificing workers: Gendered managerialism in the non-profit sector. Women's Studies International Forum. 35(5),362-371.

Baines, D., \& Cunningham, I. (2011). 'White knuckle care work': violence, gender and new public management in the voluntary sector. Work, Employment \& Society, 25(4), 760-776.

Baines, D., \& Cunningham, I. (2013). Using comparative perspective rapid ethnography in international case studies: Strengths and challenges. Qualitative Social Work, 12(1), 73-88.

Beebe, J. (2001). Rapid assessment process: An introduction. Walnut Creek: AltaMira.

Bianchi, S. and Milkie, M. (2010). Work and family research in the first decade of the 21 st century. Journal of Marriage and Family, 72(3), 705-725.

Bowen, G. (2008) Naturalistic inquiry and the saturation concept: A research note. Qualitative Research, 8(1), 137-152

Charlesworth, S (2010). The regulation of paid care workers' wages and conditions in the nonprofit sector: A Toronto case study' Relations Industrielles/Industrial Relations 65(3), 380399.

Charlesworth, S. (2012). Decent working conditions for care workers? The intersections of employment regulation, the funding market and gender norms. Australian Journal of Labour Law, 25(2), 107-129.

Charlesworth, S. \& Baines, D. (2011) 'The Impact of Government Funding Models on Work Organisation and Employee Conditions in Non-Profit Community Services' Refereed proceedings of the 25th Conference of AIRAANZ, New Zealand Work \& Labour Market Institute, AUT University, 2-4 February 2011.

Charlesworth, S. \& Marshall, H. (2011) Sacrificing workers? The curious case of salary sacrificing in non-profit community services in Australia International Journal of Public Sector Management, 24(7), 673-683.

Conaghan, J. (2004.) Women, Work and Family: A British Revolution? in Conaghan, J., Fischl, R. M., \& Klare, K. (eds.). Labour law in an era of globalization: Transformative practices and possibilities. Oxford University Press.

Creswell, J. \& Miller, D. (2000). Determining validity in qualitative inquiry. Theory into practice, 39(3), 124-130.

Cunningham, I. (2008). Employment Relations in the Voluntary Sector London: Routledge.

Cunningham, I., Baines, D. \& Charlesworth, S. (2014). 'Government Funding, Employment Conditions and Work Organization in Non-Profit Community Services: A Comparative Study', Public Administration, 92(3), 582-598.

Cunningham, I., \& James P. (2011). 'Public Service Delivery and the Voluntary Sector: Trends Explanations and Implications' in Cunningham, I., \& James, P. (eds.) Voluntary organizations and public service delivery: the employment outcomes of government outsourcing and their implications, Routledge, p 225-237.

England, P. (2005) Emerging Theories of Care Work Annual Review of Sociology, 31(1), 381-399.

Evans, B., Richmond, T. and Shields, J. (2005) Structuring neoliberal governance: The nonprofit sector, emerging new modes of control and the marketisation of service delivery. Policy and Society 24(1), 73-97. 
Evans, B. and Shields, J. (2002). The Third Sector: Neo-liberal Restructuring, Governance and the Re-making of State-Civil Society Relationships in C. Dunn (ed.) The Handbook of Canadian Public Administration Toronto: Oxford University Press: pp.236-258.

Folbre, N. (2001). The Invisible Heart: Economics and Family Values. New York: New Press.

Franzway, S. (2003) 'You Need to Care': The Work of Care between Home and Market, in Conference Proceedings, The Australian Sociological Association Annual Conference, University of New England, December 2003.

Gornick, J., \& Meyers, M. (2003). Families that work: Policies for reconciling parenthood and employment. Russell Sage Foundation.

Hampson, I. \& Junor, A. (2010). 'Putting the Process Back in: Rethinking Service Sector Skill' Work, Employment and Society 24(3): 526-545.

Hancock, L. (1999) 'Women's Policy Interests in the Market State' in L. Hancock (ed.) Women, Public Policy and the State Melbourne: Macmillan Education Australia.

Handwerker, P. (2001). Quick ethnography: A guide to rapid multi-method research. Rowman Altamira.

Harris, K. J., Jerome, N. W., Fawcett, S. B. (1997). Rapid assessment procedures: A review and critique. Human Organization, 56(3), 375-378.

Kalleberg, A. L. (2009). Precarious work, insecure workers: Employment relations in transition. American sociological review, 74(1), 1-22.

Kosny, A., \& MacEachen, E. (2010). Gendered, Invisible Work in Non-profit Social Service Organizations: Implications for Worker Health and Safety. Gender, Work \& Organization, 17(4), 359-380.

Kossek, E. E., \& Lambert, S. J. (2005). " Work-Family Scholarship": Voice and Context. Lawrence.

LeCompte, M. D., \& Schensul, J.J. (1999). Designing and conducting ethnographic research: Ethnographer's toolkit No. 1. Walnut Creek: AltaMira

McDonald, C. (2006). Challenging Social Work: The Institutional Context of Practice Houndmills, Basingstoke: Palgrave Macmillan.

McDonald, C. and Charlesworth, S. (2011). Outsourcing and the Australian Non-Profit Sector in I. Cunningham and P. James (eds.) Voluntary organisations and public service delivery: the employment outcomes of government outsourcing and their implications, Routledge, pp 185201.

Meagher, G. (2006). What can we expect from paid carers? Politics \& Society, 34( 1), 33-54.

Millen, D. (2000). Rapid ethnography: Time deepening strategies for HCI field research. Available at: portal.acm.org/citation.cfm?id $1 / 4347763$ (accessed 10 June, 2014).

Pierson, P. (2002). 'Coping with Permanent Austerity: Welfare State Restructuring in Affluent Democracies', in P. Pierson (ed.) The New Politics of the Welfare State. (pp.369-406). Oxford: Oxford University Press.

Pink, S., \& Morgan, J. (2013). Short-Term Ethnography: Intense Routes to Knowing. Symbolic Interaction, 36(3), 351-361.

Pocock, B. (2005). Work/care regimes: Institutions, culture and behaviour and the Australian case. Gender, Work \& Organization, 12(1), 32-49. 
Rasmussen, B. (2004). Between endless needs and limited resources: the gendered construction of a greedy organization. Gender, Work \& Organization, 11(5), 506-525.

Rubin, H., \& Rubin I. (2005). Qualitative Interviewing: the Art of Hearing Data. Thousand Oaks, California: Sage.

Szebehely M (2007) Carework in Scandinavia. Organisational trends and everyday realities. Conference paper, Fifth Annual ESPAnet Conference, Vienna, September.

Thompson, P., \& Smith, C. (2009). Labour power and labour process: contesting the marginality of the sociology of work. Sociology, 43(5), 913-930.

Vosko, L. F. (2002). Rethinking feminization: gendered precariousness in the Canadian labour market and the crisis in social reproduction. Robarts Canada Research Chairholders Series, 11.

Vosko, L. F. (Ed.). (2006). Precarious employment: Understanding labour market insecurity in Canada. McGill-Queen's Press-MQUP.

Vosko, L. F. (2010). Managing the Margins. Gender, Citizenship, and the International Regulation of Precarious Employment. New York. 